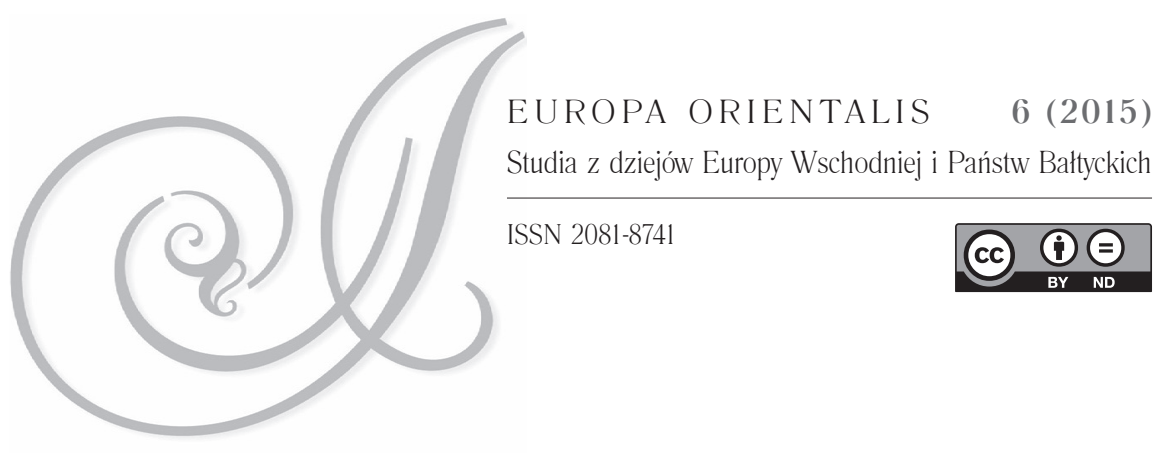

DOI: http://dx.doi.org/10.12775/EO.2015.012

\title{
Uzasadnienie przez dowództwo Grenzschutzu decyzji o rezygnacji z walki z Polską w 1919 r.
}

Prezentowany poniżej dokument wydaje się wart przedstawienia szer1 szemu gronu badaczy, gdyż stanowi dobre źródło dotyczące nastrojów niemieckiego korpusu oficerskiego w okresie przejściowym po zakończeniu I wojny światowej. Wyraźnie można z niego odczytać rozgoryczenie wojskowych brakiem poparcia ze strony ludności cywilnej koncepcji wznowienia działań wojennych. Widać także, iż jego twórca zdawał sobie sprawę, że także niżsi stopniem oficerowie, podoficerowie i żołnierze będą $\mathrm{z}$ tej decyzji niezadowoleni. Jest to tym bardziej zrozumiałe, że Niemcy według swoich własnych ocen byli przekonani, że militarnie są w stanie „zbić na kwaśne jabłko” odradzającą się Rzeczpospolitą ${ }^{1}$. Zresztą prowadzono już nawet koncentrację sił, które mogłyby zostać użyte do tego celu².

1 Słowa te padły w czasie narady generałów z 19 czerwca 1919 r. (zob. BA-MA, N 86/17, Protokoll der Sitzung in Weimar am 19.6.19 9.10 Vorm. Por. BA-MA, N 18/5, Lebenserinnerungen des Generaloberst W. Heye, T. 2, „Wie ich den Weltkrieg erlebte”, s. 517; J. Centek, Hans von Seeckt. Twórca Reichsheer, Kraków 2006, s. 209 i n.; idem, Stanowisko niemieckiego korpusu oficerskiego do kwestii podpisania traktatu wersalskiego (maj-czerwiec 1919), [w:] Rok 1918 w Europie Środkowo-Wschodniej, pod red. D. Grinberga, J. Snopka, G. Zackiewicza, Białystok 2010, s. 541-543.

2 Szerzej zob. R. Kempa, Od ,, Wojny Pozycyjnej” po „,Wiosenne Stońce”. Polska w niemieckich planach wojennych 1919 r. , „Białostockie Teki Historyczne” 2012, nr 10, s. 202 i n. 
Problemem jednakże była możliwość stawienia oporu wojskom francuskim, które w takiej sytuacji wznowiłyby działania wojenne. Wysuwano nawet pomysły podzielenia Niemiec na dwa osobne państwa - ,zachodnie” (neutralne) i „wschodnie”, które miało zająć się toczeniem wojny z Polską ${ }^{3}$. Dopiero brak poparcia ludności, wyczerpanej trwającą ponad 4 lata wojną, zmusił wojskowych do zarzucenia tych nierealnych planów ${ }^{4}$.

Warto także podkreślić, iż twórca dokumentu był przy tym świadom możliwości wypowiedzenia posłuszeństwa i buntu poszczególnych oddziałów, przed czym wyraźnie przestrzegał. Do takich sytuacji zresztą doszło później w Inflantach, gdzie dowódca VI Korpusu Rezerwowego, generał Rüdiger von der Goltz, działał samowolnie, a część jego żołnierzy przeszła nawet pod dowództwo „białych” Rosjan, by kontynuować walkę pod ich sztandarami ${ }^{5}$. Ostatnim zaś wstrząsem tego typu był pucz Kappa-Lüttwitza w marcu $1920 \mathrm{r}^{6}$

Publikowany dokument pochodzi z zespołu Dowództwa Północ (Armeeoberkommando Nord), które nadzorowało działania Grenzschutzu na północnym odcinku frontu wschodniego ${ }^{7}$. Oznaczony jest sygnaturą PH 5-II/4. W związku z niedawną rocznicą wybuchu I wojny światowej zarówno ten, jak i pozostałe zespoły dowództw niemieckich armii z okresu I wojny światowej, zostały zmikrofilmowane i obecnie udostępnia się je w takiej postaci.

Dokument nie posiadał niestety daty, toteż trudno z całą pewnością określić moment jego powstania. Wydaje się jednak, że mogło to mieć miejsce krótko po naradach, przeprowadzonych w dniu 19 czerwca 1919 r.,

3 Niederschrift über die Besprechung mit dem riegsminister in Weimar am 18.6.1919, [w:] Annehmen oder ablehnen? Das Kabinett Scheidemann, Oberste Heeresleitung und Vertrag von Versailles im Juni 1919. Fünf Doumente aus dem Nachlaß des Hauptmanns Günther von Poseck, wyd. H. Mühleisen, „Vierteljahrshefte für Zeitgeschichte” 1987, nr 3, s. 438-442; J. Centek, Stanowisko..., s. 542.

${ }^{4}$ Szerzej zob. BA-MA, N 86/17, Protokoll der Sitzung in Weimar am 19.6.19 9.10 Vorm; J. Centek, Stanowisko..., s. 542-545.

${ }^{5}$ Szerzej na temat działań niemieckich zob. np. R. von der Goltz, Meine Sendung in Finnland und im Baltikum, Leipzig 1920, Der Feldzug im Baltikum bis zur zweiten Einnahme von Riga. Januar bis Mai 1919, Berlin 1937; Der Feldzug im Baltikum nach der zweiten Einnahme von Riga. Juni bis Dezember 1919, Berlin 1938; T. Paluszyński, Walka o niepodległość Łotwy 1914-1921, Warszawa 1999; J. Centek, Baltische Landeswehr, encyclopedia.1914-1918-online.net/article/Baltische Landeswehr (dostęp: 19.12.2015); idem, Baltenregiment, encyclopedia.1914-1918-online.net/article/Baltenregiment (dostęp: 19.12.2015).

${ }^{6}$ Szerzej zob. J. Centek, Reichsheer ery Seeckta (1921-1926), Warszawa 2010, s. 65-72; idem, Hans von Seeckt..., s. 218-232.

7 Szerzej zob. idem, Hans von Seect..., s. 197-199; R. Kempa, op. cit., s. 193. 
kiedy to zdecydowano się zrezygnować z walki, m.in. właśnie ze względu na niechętną jej postawę ludności ${ }^{8}$. Za termin ante quam można uznać 28 czerwca 1919 r., czyli podpisanie traktatu wersalskiego, gdyż z jednej strony w tekście nie ma słowa na temat zawarcia pokoju, z drugiej zaś jego akceptacja była całkowitą rezygnacją z walki i wydawanie takiego dokumentu byłoby pozbawione sensu.

Według rozdzielnika dokument został wydany w 32 egzemplarzach. Po 3 sztuki otrzymały dowództwa ,wschodnich” Korpusów: I, II, XVII, XX oraz VI Ochotniczego Korpusu Rezerwowego, Dowództwo Korpusu L, sztab 4 DP. Z kolei po jednym egzemplarzu przekazano do gubernatorstw twierdz Toruń, Grudziądz oraz Królewiec. W Dowództwie Północ zatrzymano 5 sztuk.

Niestety czytelność oryginału pozostawia już wiele do życzenia i z tego względu konieczne było dokonanie odpisu. $\mathrm{Z}$ tego względu mogło niestety dojść do przeinaczenia pojedynczych wyrazów. Natomiast odczytanie niektórych słów nie było w ogóle możliwe, co też zostało zaznaczone w tekście.

Jeżeli w oryginale miały miejsce powtórzenia niektórych wyrazów (np. „walki”), zostało to oddane również w poniższym tłumaczeniu.

Jarosław Centek

${ }^{8}$ BA-MA, N 86/17, Protokoll der Sitzung in Weimar am 19.6.19 9.10 Vorm; J. Centek, Stanowisko..., s. 542-545. 
Dowództwo Północ

Ia $\mathrm{Nr} 90$ geh. op.

Napisane przez oficera

Poufne!

\section{Dlaczego nie możemy walczyć i nie wolno nam walczyć}

Dowództwo Północ musiało podjąć decyzję o zarzuceniu pierwotnego planu, zbrojnej obrony Marchii Wschodniej ${ }^{9}$ przed Polakami. Rozstrzygające dla tej nadzwyczaj ciężkiej decyzji były nastroje dużej części ludności, nie tylko w pozostałych Niemczech, lecz właśnie w odnośnych prowincjach. Od dawna Dowództwo stało na stanowisku, że nowa walka była uzasadniona i możliwa tylko w porozumieniu $\mathrm{z}$ władzami i narodem. Na tym bazowały wszystkie przygotowania, rozbudowa i wychowanie wojska do walki. $\mathrm{Z}$ wypowiedzi krótko po ogłoszeniu warunków pokoju, z licznych manifestacji w mieście i na wsi, trzeba było przyjąć, że zbrojny opór odpowiada odczuciom narodu. W każdym razie już wówczas musiało dziwić, że z zagrożonych prowincji stosunkowo mało ludzi chwytało za broń. Większość preferowała pozostawienie obrony ich ojczyzny [osobom o] narodowych zapatrywaniach z reszty Niemiec. ${ }^{a}[\ldots]^{\mathrm{a}}$ decyzja pod tym względem w pełni pozwoliła oszacować nastroje, że większa część narodu w Marchii Wschodniej wcale nie życzy sobie ${ }^{10}$ walki, woli raczej spokojnie iść do Polski, niż widzieć swoją ojczyznę, swoje mienie wydane na niebezpieczeństwa i niepewny los wojny ${ }^{\mathrm{b}}$. Nie miała hartu i odwagi, by poprzeć czynem swoje wielkie słowa. Dowództwo musi z całą jasnością podkreślić, że to nie wojskowi przywódcy ${ }^{\mathrm{s}}$ się ociągalic przed wielką decyzją, lecz postawa całego narodu z góry pozwalała dostrzec nową walkę jako tak beznadziejną, że nie można było brać jej pod uwagę.

Dowództwo rezygnuje z dokładnego przedstawienia sytuacji militarnej. Jest ona znana każdemu oficerowi służącemu w Grenzschutzu.

Tym bardziej każdy oficer musi przyznać, że w tej sytuacji walka tylko wtedy ma widoki na sukces, gdy rząd, naród i armia są w ${ }^{\mathrm{d}}$ najgłębszej $^{\mathrm{d}}$ jedności. Zamiast tego już kilka dni przed podpisaniem [traktatu] poko-

9 Niem. Ostmark. Historyczny termin, użyty w tekście na określenie prowincji wschodnich, które po I wojnie światowej Rzesza Niemiecka utraciła na rzecz Polski.

a-a Wyraz nieczytelny.

${ }^{10}$ Oryginalne podkreślenia w tekście zastąpiono wytłuszczeniami.

b-b Ze względu na niemożliwość odczytania pierwszego wyrazu, tłumaczenie tego zdania nie jest pewne.

c-c Fragment mało czytelny, tłumaczenie nie jest pewne.

d-d Wyraz nieczytelny, tłumaczenie z kontekstu. 
jowego wszyscy przedstawiciele Marchii Wschodniej wyjaśnili, że naród jest zdecydowanie przeciwny walce. Władze odmówiły swojego wsparcia i według wypowiedzi partii socjaldemokratycznych w razie walki należy się liczyć z unieruchomieniem kolei na naszych tyłach. Zupełnie niezależnie od tego, że oddziały walczące wbrew rozkazowi swojego rządu należy uznać za buntowników i odpowiednio potraktować, brak możliwości sukcesu musiał prowadzić do rezygnacji z walki.

Dowództwo zwraca się z tymi wyjaśnieniami do rozsądku oficera i prosi o jego współdziałanie przy instruowaniu żołnierzy. Nie będzie lekko pouczyć żołnierzy, którzy od dawna są przygotowani do walki, eby przyjęli rezygnacjęe. Bez wątpienia będzie to jednak możliwe dla przywódcy, który ma swoich żołnierzy mocno w garści.

Dowództwo zwraca się przecież także do poczucia obowiązku oficerów i życzy [sobie], by po tym rozstrzygającym stanowisku dowództwa nie dochodziło więcej do żadnych specjalnych działań pojedynczych oficerów. Należy je tym bardziej potępić jako wojskowe niepowodzenia i przyczynią się [one] tylko do niepokoju i niejasności wśród żołnierzy i ludności i jeszcze utrudnią nieskończenie trudne dzieło wycofania wojsk ${ }^{11}$. Dla żołnierza była zawsze tylko ostateczna decyzja. My ją teraz - z ciężkim sercem - przeforsowaliśmy, by rezygnować z walki, żeby nie było już więcej dla walki żadnego foglądania się za siebie z żalem ${ }^{\mathrm{f}}$, żadnego połowicznego ${ }^{\mathrm{g}}[\ldots]^{\mathrm{g}}$, żadnego więcej roztrząsania tej myśli. Nasza energiczna praca musi być poświęcona pokojowej odbudowie.

Żaden oficer nie może zapomnieć, że samodzielne wojskowe powstanie wbrew woli narodu i rządu musi prowadzić do najcięższej wewnętrznej walki do doniosłego w skutkach rozłamu w naszym narodzie.

Wprawdzie w stanie największej słabości możemy stracić ${ }^{\mathrm{h}}[\ldots]^{\mathrm{h}}$. Ale niech każdy zastanowi się, że możemy to niegdyś odzyskać tylko, gdy pozostanie zachowane źródło naszej siły:

nasza wewnętrzna jedność!

$$
\begin{array}{r}
z[\mathrm{e}] \mathrm{s} \text { [trony] D[owództwa] } \\
\text { Szef sztabu } \\
{ }^{\mathrm{i} H e y e^{\mathrm{i}}}
\end{array}
$$

\footnotetext{
e-e Czasownik jest nieczytelny, przez co tłumaczenie fragmentu nie jest pewne.

${ }^{11}$ Chodzi o ewakuację wojsk niemieckich z terytoriów zajętych w toku walk na froncie wschodnim. Zob. szerzej: Die Rückführung des Ostheeres, Berlin 1936.

$\mathrm{f}-\mathrm{f}$ Tekst mało czytelny i tłumaczenie tego fragmentu nie jest pewne.

g-g Wyraz nieczytelny.

h-h Wyraz nieczytelny.

i-i Czytelny podpis odręczny.
} 